Journal of Engineering and Applied Sciences 14 (9): 2943-2950, 2019

ISSN: 1816-949X

(C) Medwell Journals, 2019

\title{
Identity of Living Museums in Thailand
}

\author{
${ }^{1}$ Kunakorn Sailuadkham, ${ }^{2}$ Niyom Wongpongkham and ${ }^{3}$ Sarunya Prasopchingchana \\ ${ }^{1888 / 48}$ Moo 5, Alley 6, PS Home Maliwan Village, Maliwan Road, Ban Ped Sub-District, \\ Muang Khon Kaen District, 40000 Khon Kaen Province, Thailand \\ ${ }^{2}$ Department of Art and Cultural Research, Faculty of Fine and Applied Arts, \\ Khon Kaen University, Mittrapap Road, Nai Muang Sub-District, \\ Muang District, 40000 Khon Kaen Province, Thailand \\ ${ }^{3}$ Department of History, Faculty of Humanities and Social Sciences, Burapha University, \\ Long Hat Bang Saen Road, Saen Suk Sub-District, Muang Chonburi District, \\ 20131 Chonburi Province, Thailand
}

\begin{abstract}
This research purposes to study the identity of living museums in Thailand where are the new form of museums in Thailand in order to indicate the unique natures and see if they are outstanding and different from general museums in order to attract more tourists to visit the museums. The researcher conducted the research on two living museums in Thailand: Baan Khi Lek Yai Living Museum in Chaiyaphum Province and Mueang Mae Hong Son Living Museum in Mae Hong Son Province in order to collect field data and apply their identities to the framework for data analysis to identify the identities of living museums in Thailand. The findings revealed that the identities of living museums in Thailand were that: the living museums did not have exhibition buildings, the living museums contained local items and wisdoms from the area where the museums were located and no items were displayed in one particular room or building, the living museums showed people's real lifestyles in the community and the living museums did not have curators to facilitate or provide information to visitors. However, the local people would guide visitors or provide information by themselves.
\end{abstract}

Key words: Identity, museum, living museum, Thailand, lifestyles, information

\section{INTRODUCTION}

A museum, for Thai people was first established in the reign of King Chulalongkorn (Rama V). The king graciously established the first museum in Kong Cordia Hall or Haruthai Association Pavilion in the grand palace and held the opening ceremony in 1874 (ONM., 2012). Until present, the number of museums in Thailand has continuously increased and improved, the total number of which is 1,425 museums in Thailand. The museums can be classified into more than 250 types nationwide, e.g., art and archaeology museum, ethnography museum, science museum, agriculture museum, technical museum, local museum, historical park, etc. In addition, there are museums under other affiliations such as Royal Thai Air Force museum, police museum, forestry museum etc. In addition, there are private museums such as Suan Pakkad Palace Museum, Children's Museum, Baan Jatawee, Small Boat Museum, Ancient Cities and etc. (ONM., 2012). However, many museums apply new technology with an exhibition for more interests (Phosrithong, 2011). Some are affected by the fact that the world now a days develops technology faster, therefore, museums cannot follow a previous idea. It is necessary to change, improve and develop to make museums more interesting and modern and attract people to visit and make use of museums (ONM., 2012). Hence, all types of Thai museums in the new century are improved, changed the type of presentation and display in exhibitions, activities and processes including network working (Srisak, 2002) to conform to changed technology that may inspire people to visit museums more than the past as a result, there are new types of more interesting museums. A living museum is one of those museums where was established under a new idea differentiating from the older one of general museums new presentation and display are not only held in the building.

When generally thinking of the word "Museum", people will think of "a place where gathers and shows an important thing to cultures or sciences for the purpose of education and enjoyment" (Royal Institute of Thailand, 2003) or a building with artifacts or considered gathering

Corresponding Author: Sarunya Prasopchingchana, Department of History, Faculty of Humanities and Social Sciences, Burapha University, Long Hat Bang Saen Road, Saen Suk Sub-District, Muang Chonburi District, 20131 Chonburi Province, Thailand 
lifestyles, tools and artifacts of people in a society that are researched until more understanding those arts. They will be shown in a showcase as a photograph, a statue or other kinds of displays to share the knowledge to common people, for example, a museum exhibited the past's story of the community it was plenty of artifacts or tools in those ages being shown. Also, the story was summarized that visitors could have the chance to listen to and read its story depending on an imagination. However, the word "Living museum" has not the same meaning with the word "Museum" because a living museum is a place where specifically indicates lifestyles how to use tools used in the actual life without creating any imaginations comparing to general museums (Walaiporn, 2010).

However, the word "Living museum" are defined in many terms. According to the following examples, Nitithep Chaiya stated that a living museum is a place where exhibits people's lifestyles in a society and culture it indicates how the local people's actual lifestyles are still, the local people maintain the original lifestyles and they have been followed until they become the community identity such as houses, food, costumes, languages, beliefs, traditions, rites, etc. Burim Otkanon stated that a living museum is place where specifically exhibits people's lifestyles and tools used in the actual life without creating any imaginations comparing to general museums. Pun Tiangburanatham stated that a living museum is a place where specifically maintains "An instrumental and symbolic object" that is empirical evidence and maintains "A lifestyle" that is a dimension from many things gathered and collected for a long time until it becomes the local identity. Thereby, the type of museum is not a dead museum where breaks off between tourists and the local identity by the knowledge of modern museum exhibition but it is a living museum where promotes the lifestyle with identity value to be still available. Nitaya Kanokmongkol stated that a living museum is a place with the exhibition type and atmosphere completing life to architecture and indicating lifestyles of the people related to an open-air museum, a folk museum or an eco-museum, so that, visitors can touch and feel the content such as staying in the atmosphere in the old days, meeting culture owners or experiencing what is exhibited (Kanokmongkol, 2011). Hence, the word "living museum" here is defined that a type of the museum where is not specifically exhibited in the building like general museums but focusing on real lifestyles, actual lifestyles of the people in a society including cultures that have been maintained and followed until it becomes the community identity.

A living museum is exhibited in a wide area or an outdoor area because it indicates people's lifestyles. It was believed that the first concept of a living museum came from Scandinavia. Later, this concept was spread over Europe and North America. Sometimes, a living museum was variously called such as an open-air museum, a constructional museum, a local museum, etc., However, it depends on the context and its location; For example in North America, this kind of museum is called "Living museum" the first living museum of North America was located in green field village, Michigan, USA; Established by Henry Ford in 1928 for the purpose as the museum where collected personal belongings. Next, in 1934 it became the model of a living museum newly established over the world. At the present time, the concept of a living museum is spread over the world. Each living museum has its own unique nature; For example, a living museum in North America specifically holds an exhibition always maintaining cultures, natures and histories in the area whereas a living museum in Europe will be different it significantly maintains the aspect of buildings and construction.

There are 3 natures of living museum divided as follows: site or model that reproduces people's lifestyles at one particular moment in time, real lifestyle that indicates people's real lifestyles still maintained and followed and atmosphere creation that completes life to architecture and indicating lifestyles of the people related to an open-air museum, a folk museum or an eco-museum, so that, visitors can touch and feel the content such as staying in the atmosphere in the old days, meeting culture owners or experiencing what is exhibited, etc. (Kanokmongkol, 2011).

According to the information from Princess Maha Chakri Sirindhorn Anthropology Center it shows that there are totally 1,452 museums in Thailand. There are up to 545 museums where exhibit local lifestyles and wisdoms but there are only 2 museums under the official name "Living museum" where are usually open (the information on 28th February 2017) (Princess Maha Chakri Sirindhorn Anthropology Center, n.d.) comprising of Baan Khi Lek Yai Living Museum in Chaiyaphum Province and Mueang Mae Hong Son Living Museum in Mae Hong Son Province.

However, establishment of general museums in Thailand is without distinct rules and regulations except the National Museum of Thailand under the control of the Department of Fine Arts that must follow the rules and regulations formulated by the Department of Fine Arts. Therefore, general museums are established with different types or natures according to the context of each museum. However, even if without distinct rules and regulations of general museums establishment to establish any types of museums is based on the internal factors: the physical factor comprising of a location, a building an artifact or what supports the story, a content and a presentation method, the organization structure and 
personnel comprising of a museum director from the General Administration Division and the budget comprising of a budget used to establish and administer a museum and the external factors: the target group, museum clients, comprising of students, university students, academicians, researchers, monks, novices or priests from other religions, a variety of museum members, common people and foreign tourists, the governmental policy: the policy in accordance with the Act of Decentralization Procedure and Planning to the Local Administrative Organization B.E. 2542 (1999) and the policy in accordance with the National Education Act B.E. 2542 (1999), the stakeholders comprising of organization executives, crown servants, employees or workers, professional board, clients or customers, service persons in a museum, government, mass media, competitors, museum networks, local communities, organizations, agencies and people in general and the need of people and community (ONM., 2012).

Furthermore, at the present time, the identity concept is applied to establish many museums for administration. As the comprehension, the identity or uniqueness of museums is a part of community development. For example, Sayun Praichanjit thought that the identity of the local community through museum administration was considered a tool and a way in the other community developing process. Srisak Walliphodom thought that to find the local identity was the significant task in the museum administration and created a co-learning process in the community. Sirirat Sisombut who was studying the community learning center and the ethnic identity recovery of Song people, thought that the museum identity and the identity recovery were considered the process of conserving and recovering a culture of communities or ethnics. The Spertus Institute for Jewish Studies which was studying globalization, museum and identity evolution, revealed that the museum development proper to the age of globalization would consider the following 7 steps: pride and right, museum for social changes, architecture, competition for capital acquisition and audience, definition of responsibility, artifact collection and storage and identity (Walaiporn, 2010).

It is apparent that the museum identity or creation of museum identity is really necessary for all types of museum now a days, especially a living museum where is quite new in Thailand showing uniqueness, remarkableness and difference comparing to general museums, so as to interest and attract more tourists to visit a museum.

Research objective: This research purposes to to study the identity of living museums in Thailand where are the new form of museums in Thailand in order to indicate the unique natures and see if they are outstanding and different from general museums in order to attract more tourists to visit the museums.

\section{MATERIALS AND METHODS}

The researcher studied the identity of living museums in Thailand by visiting two living museums in Thailand as follows: Baan Khi Lek Yai Living Museum in Chaiyaphum Province and Mueang Mae Hong Son Living Museum in Mae Hong Son Province in order to collect the field data based on the qualitative research tool comprising of a survey, a non-participation observation, a structured interview and a non-structured interview. Then the obtained data were categorized, summarized and analyzed for the identity of living museums in Thailand. The elements of two living museums above were analyzed and compared to find a significant co-nature of the living museum before analyzing the result and comparing to the element of general museums. The concept of identity was applied as the framework to analyze the data for the identity of living museums in Thailand that was the unique nature of those people or things it was the feeling to remind themselves that "Who they are" or "How are they different from other people" from an association between themselves and other people by consideration from themselves and other people at that moment. Those people or things may have included many identities created and followed by the social process. The fact that humans considered themselves may have been different from the fact that other people considered. Moreover, the concept of identity and museum work was used to analyze the data to depict the concept of identity used in museum administration more clearly.

\section{RESULTS AND DISCUSSION}

Research findings: The findings revealed the identity of living museums in Thailand as follows: the living museum without constructing its building for presentation, the living museum with artifacts pertaining to local lifestyles and wisdoms of the community where the museum was located artifacts were not exhibited together at any particular rooms or any buildings, the living museum exhibiting real lifestyles and the living museum without any curators who were responsible for guiding or giving the information people from the community were responsible for guiding or giving the information themselves instead on the following details: 
Baan Khi Lek Yai Living Museum in Chaiyaphum Province: It was located at Baan Khi Kek Yai, Nai Mueang Sub-district, Mueang District, Chaiyaphum Province, considered $3 \mathrm{~km}^{2}$ and covering the whole area of Baan Khi Lek Yai Community. It was the museum without permanent or temporary buildings for exhibition. The exhibited artifacts pertaining to local life styles and wisdoms of Baan Khi Lek Yai community in Chaiyaphum Province were local houses applied with cement, Phasin, cotton Phasin, artificial long nails, Kan Yao, Kan Sam Tao, Klong Dor, Klong Seng, etc. with the content of local life styles and wisdoms of Baan Khi Lek Yai Community in Chaiyaphum Province; in addition, it was the museum where exhibited real life styles and usual life styles of people in the community.

Moreover, Baan Khi Lek Yai Living Museum in Chaiyaphum Province had not any curators who were responsible for guiding or giving the information like general museums because everyone in the community would be able to guide or give the information about a story. The museum opened every day (please contact a museum official before visiting) without any service charges. It was administered by the temple and the community. The museum had the significant roles as follows: to exhibit about local life styles and wisdoms of Baan Khi Lek Yai community in Chaiyaphum Province with a long history it narrated the story of "Baan Jao and Baan Nai" and lifestyles, traditions and original cultures were conserved and followed, so far, to be the new tourist attraction where provided all kinds of knowledge and enjoyment to people in all ages and educational levels, to be the life time learning center where enhanced and

(a)
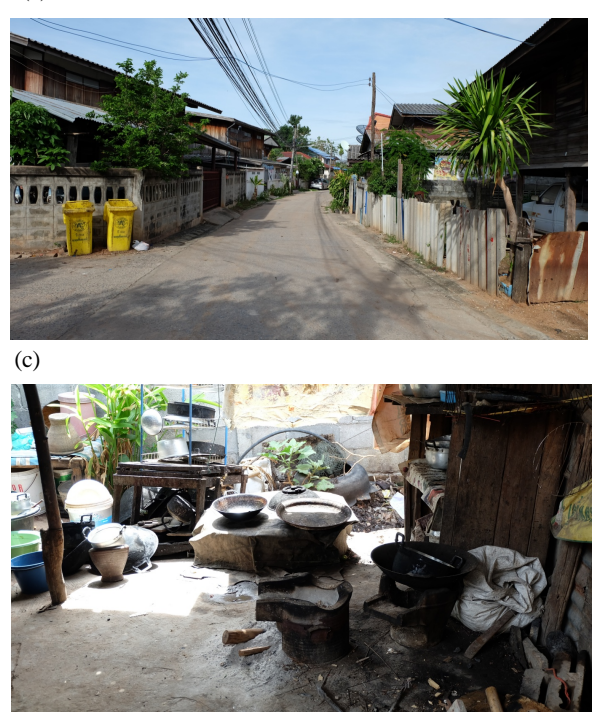

developed people's wisdoms at a community level, a provincial level and a national level and to conserve lifestyles, traditions, rites or practices of the community existed from the past as follows: 12 month, tradition or called "Hit Sibsong", "Joey Bung Fai Tradition", "Dor Klong Tradition" and "Pao Kan Sam Tao Tradition" considered the famous cultures and could not be seen in other provinces, etc.

Baan Khi Lek Yai Living Museum was plenty of the elements indicating its natures as follows: it was located in the community area the community story was applied to exhibition, its size depended on the community area where the museum was located, there were no permanent or temporary buildings for exhibition, there were artifacts pertaining to local life styles and wisdoms of the community where the museum was located the museum did not exhibit artifacts together at any particular rooms or buildings, there was the content of local life styles and wisdoms of the community where the museums were located, it exhibited real life styles and usual life styles of people in the community, there were no curators who were responsible for guiding or giving the information people from the community would be responsible for guiding or giving the information instead, it opened every day (please contact a museum official before visiting) without any service charges, it was administered by the temple and the community and it directly played a role of exhibiting, being the new tourist attraction, being the lifetime learning center and conserving life styles, traditions, rites or practices of the community existed from the past and indirectly played a role of social service and public relations (Fig. 1).

(b)

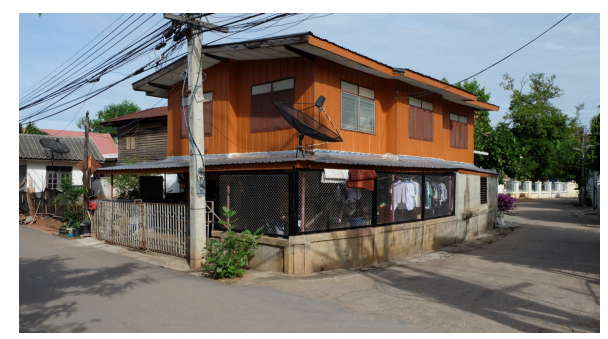

(d)

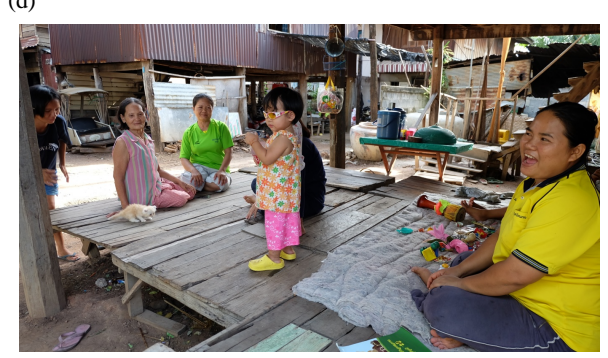

Fig. 1: a-d) Baan Khi Lek Yai Living Museum in Chaiyaphum 
Mae Hong Son Living Museum in Mae Hong Son Province: It was located in the city center of Mae Hong Son Province, considered $6 \mathrm{~km}^{2}$ (if excluding the airport, it remained $4 \mathrm{~km}^{2}$ ) without permanent or temporary buildings for exhibition. The exhibited artifacts pertaining to local life styles and wisdoms of Mae Hong Son community in Mae Hong Son Province, especially the story of Tai people (Tai Yai) who were original local people of Mae Hong Son Province such as architecture with unique natures and historical stories, local houses, etc. with the content of local life styles and wisdoms of Mae Hong Son Community in Mae Hong Son Province especially the story of Tai people (Tai Yai) who were original local people of Mae Hong Son Province in addition it was the museum where exhibited real life styles and usual life styles of people in the community.

Furthermore, this museum had no curators who were responsible for guiding or giving the information like general museums because all Mae Hong Son people could guide or tell the story of lifestyles, traditions and cultures themselves. There were museum officials who always suggested more information. This museum opened every day from $8.30 \mathrm{am}-4.30 \mathrm{pm}$ without any service charges. It was administered by the community and Mae Hong Son municipality with the following roles: to exhibit about architecture with unique natures and historical stories, houses where people still lived in, cultures, traditions and languages presented from routines that were followed, so far, to be the new tourist attraction where provided all kinds of knowledge and enjoyment to people in all ages and educational levels, to be the life time learning center where enhanced and developed people's wisdoms at a

(a)

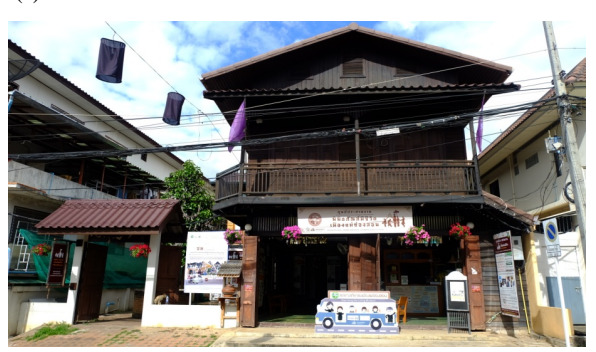

(c)

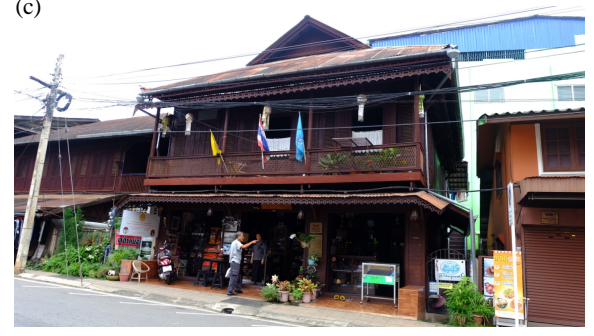

community level, a provincial level and a national level, to protect or control the city between the "Cultural heritage city" and the trend of tourism counted as the cause of invasion negatively affecting the cultural city and people's lifestyle, to administer the "Cultural heritage city" with the main point of tourism by the urban area system that emphasized the community to be responsible and have activities conforming to the participatory process of the community the operational center was "Living museum coordination center", to develop the city conforming to the context of conservative tourist cities that did not only respond to tourism but also considering benefits and people's life quality with the significant concept of development which was conservation would be successful if development was operational and to recover the city and add the value to ancient remains, temples and buildings in the pattern of local architectures including cultures and life styles to conserve for people in next generations it depended on cooperation from educational institutes in order to implant the concept of realizing the value of cultures majorly run by youths for recovery with the living museum process.

In Fig. 2, Mae Hong Son Living Museum was plenty of the elements indicating its natures as follows:it was located in the community area the community story was applied to exhibition, its size depended on the community area where the museum was located, there were no permanent or temporary buildings for exhibition, there were artifacts pertaining to local life styles and wisdoms of the community the museum did not exhibit artifacts together at any particular rooms or buildings, there was the content of local life styles and wisdoms of the

(b)

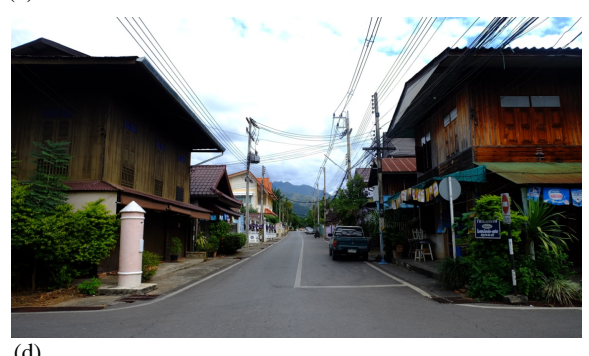

(d)

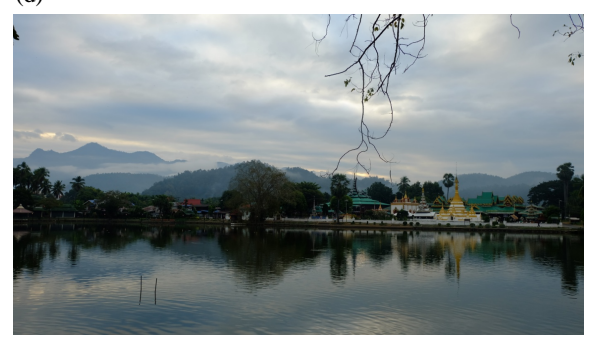

Fig. 2: a-d) Mae Hong Son Living Museum in Mae Hong Son Province 
Table 1: Comparison between elements of living museums in Thailand

\begin{tabular}{|c|c|c|c|c|}
\hline $\begin{array}{l}\text { Living museum/ } \\
\text { Elements }\end{array}$ & $\begin{array}{l}\text { Baan Khi Lek Yai Living } \\
\text { Museum in Chaiyaphum } \\
\text { Province }\end{array}$ & $\begin{array}{l}\text { Mae Hong Son Living } \\
\text { in Mae Hong Son } \\
\text { Province }\end{array}$ & $\Rightarrow$ & Living museum \\
\hline Location & $\begin{array}{l}\text { Located at the community area } \\
\text { with the community story as the } \\
\text { framework in the exhibition }\end{array}$ & $\begin{array}{l}\text { Located at the community area } \\
\text { with the community story as the } \\
\text { framework in the exhibition }\end{array}$ & $\Rightarrow$ & $\begin{array}{l}\text { Located at the community area with the } \\
\text { community story as the framework in the } \\
\text { exhibition }\end{array}$ \\
\hline Size & $\begin{array}{l}\text { Size depending on the community } \\
\text { area where the museum was located at }\end{array}$ & $\begin{array}{l}\text { Size depending on the community } \\
\text { area where the museum was located at }\end{array}$ & & $\begin{array}{l}\text { Size depending on the community area } \\
\text { where the museum was located at }\end{array}$ \\
\hline $\begin{array}{l}\text { Museum } \\
\text { building }\end{array}$ & $\begin{array}{l}\text { No permanent or temporary buildings } \\
\text { for exhibition }\end{array}$ & $\begin{array}{l}\text { No permanent or temporary buildings } \\
\text { for exhibition }\end{array}$ & $\Rightarrow$ & $\begin{array}{l}\text { No permanent or temporary buildings } \\
\text { for exhibition }\end{array}$ \\
\hline Artifact & $\begin{array}{l}\text { Local lifestyles and wisdoms of the } \\
\text { community where the museum was } \\
\text { located at and artifacts were not exhibited } \\
\text { together at any particular rooms or } \\
\text { buildings }\end{array}$ & $\begin{array}{l}\text { Local lifestyles and wisdoms of the } \\
\text { community where the museum was } \\
\text { located at and artifacts were not } \\
\text { together at any particular rooms or } \\
\text { buildings }\end{array}$ & $\Rightarrow$ & $\begin{array}{l}\text { Local lifestyles and wisdoms of the } \\
\text { community where the museum was located } \\
\text { at and artifacts were not exhibited together } \\
\text { at any particular rooms or buildings }\end{array}$ \\
\hline Content & $\begin{array}{l}\text { Local lifestyles and wisdoms of the } \\
\text { community where the museum was } \\
\text { located at }\end{array}$ & $\begin{array}{l}\text { Local lifestyles and wisdoms of the } \\
\text { community where the museum } \\
\text { was located at }\end{array}$ & $\Rightarrow$ & $\begin{array}{l}\text { Local lifestyles and wisdoms of the } \\
\text { community where the museum was } \\
\text { located at }\end{array}$ \\
\hline Presentation & $\begin{array}{l}\text { Indicating real lifestyles and usual } \\
\text { lifestyles of people in the community }\end{array}$ & $\begin{array}{l}\text { Local lifestyles and wisdoms of the } \\
\text { community where the museum was } \\
\text { located at and artifacts were not exhibited } \\
\text { together at any particular rooms or } \\
\text { buildings }\end{array}$ & $\Rightarrow$ & $\begin{array}{l}\text { Local lifestyles and wisdoms of the } \\
\text { community where the museum was } \\
\text { located at and artifacts were not exhibited } \\
\text { together at any particular rooms or } \\
\text { buildings }\end{array}$ \\
\hline $\begin{array}{l}\text { Information } \\
\text { providing }\end{array}$ & $\begin{array}{l}\text { No curators the community would be } \\
\text { responsible for guiding or giving the } \\
\text { information instead }\end{array}$ & $\begin{array}{l}\text { No curators the community would be } \\
\text { responsible for guiding or giving the } \\
\text { information instead }\end{array}$ & $\Rightarrow$ & $\begin{array}{l}\text { No curators the community would be } \\
\text { responsible for guiding or giving the } \\
\text { information instead }\end{array}$ \\
\hline Service & $\begin{array}{l}\text { Opened every day (please contact the } \\
\text { museum official before visiting) without } \\
\text { any service charges }\end{array}$ & $\begin{array}{l}\text { Opened every day (from } 8.30 \mathrm{am}-4.30 \mathrm{pm} \text { ) } \\
\text { without any service charges }\end{array}$ & $\Rightarrow$ & $\begin{array}{l}\text { Opened every day without any service } \\
\text { charges }\end{array}$ \\
\hline $\begin{array}{l}\text { Organization } \\
\text { structure }\end{array}$ & $\begin{array}{l}\text { Administered by the temple and the } \\
\text { community }\end{array}$ & $\begin{array}{l}\text { Administered by the community and } \\
\text { Mae Hong Son Municipality }\end{array}$ & $\Rightarrow$ & Administered by the community \\
\hline Role & $\begin{array}{l}\text { Exhibiting tourist attraction and lifetime } \\
\text { learning center, conserving lifestyles and } \\
\text { servicing societies and public relations }\end{array}$ & $\begin{array}{l}\text { Exhibiting tourist attraction and lifetime } \\
\text { learning center, conserving lifestyles and } \\
\text { servicing societies and public relations }\end{array}$ & $\Rightarrow$ & $\begin{array}{l}\text { Exhibiting a story of local lifestyles and } \\
\text { wisdoms of the community where the } \\
\text { museum was located }\end{array}$ \\
\hline
\end{tabular}

community where the museums were located, it exhibited real lifestyles and usual life styles of people in the community, there were no curators who were responsible for guiding or giving the information people from the community would be responsible for guiding or giving the information instead, it opened every day (from $8.30 \mathrm{am}-4.30 \mathrm{pm}$ ) without any service charges, it was administered by the community Mae Hong Son municipality and it directly played a role of exhibiting, being the new tourist attraction, being the life time learning center and conserving lifestyles, traditions, rites or practices of the community existed from the past and indirectly played a role of social service and public relations.

According to the abovementioned information, it was clear that two living museums comprising of Baan Khi Lek Yai Living Museum in Chaiyaphum Province and Mae Hong Son Living Museum in Mae Hong Son Province had the elements indicating co-natures of the living museums as Table 1 follows: the museums were located in the community area the community story was applied to exhibition, their size depended on the community area where they were located, there were no permanent or temporary buildings for exhibition, there were artifacts pertaining to local lifestyles and wisdoms of the community where the museum were located the museum did not exhibit artifacts together at any particular rooms or buildings, there was the content of local lifestyles and wisdoms of the community where the museums were located, the museums exhibited real lifestyles and usual lifestyles of people in the community, there were no curators who were responsible for guiding or giving the information people from the community would be responsible for guiding or giving the information instead, the museums opened every day without any service charges, the museums were administered by the community and the museums played a key role of exhibiting stories, local lifestyles and wisdoms of the community where the museums were located.

However, when comparing and analyzing the elements of living museums with the elements of general museums it was shown that living museums provided the elements with unique natures different from natures of general museums. They were clearly shown in detail as Table 2 follows: the living museums did not construct buildings for exhibition with the key concept that was to use all of the community area for exhibition, therefore, there were no buildings for exhibition like general museums, the living museums were full of artifacts pertaining to local life styles and wisdoms of the 
Table 2: Comparison between elements of general museum and elements of living museum in Thailand

\begin{tabular}{|c|c|c|c|c|}
\hline $\begin{array}{l}\text { Living museum/ } \\
\text { Element }\end{array}$ & $\begin{array}{l}\text { General museum } \\
\text { (National museum) }\end{array}$ & Living museum & $\Rightarrow$ & Nature \\
\hline Location & $\begin{array}{l}\text { Located in the area where is developed,the easily } \\
\text { accessed or in important area such as an official } \\
\text { place, a historical place, a historical site, etc. }\end{array}$ & $\begin{array}{l}\text { Located at the community area with the } \\
\text { community story as the framework in the } \\
\text { exhibition }\end{array}$ & $\Rightarrow$ & Unclear \\
\hline Size & $\begin{array}{l}\text { Size depending on the place where the museum } \\
\text { was located at }\end{array}$ & $\begin{array}{l}\text { Size depending on the community area where the } \\
\text { museum was located at }\end{array}$ & $\Rightarrow$ & Similar \\
\hline $\begin{array}{l}\text { Museum } \\
\text { building }\end{array}$ & Constructing the museum building for exhibition & No permanent or temporary buildings for exhibition & $\Rightarrow$ & Clearly deifferent \\
\hline Artifact & $\begin{array}{l}\text { Different based on the type of museums, gathering } \\
\text { artifacts and seeking artifacts outside that were } \\
\text { exhibited together in one particular room or building } \\
\text { by clearly categorizing artifacts }\end{array}$ & $\begin{array}{l}\text { Local lifestyles and wisdoms of the community where } \\
\text { the museum was located at and artifacts were not } \\
\text { exhibited together at any particular rooms or buildings }\end{array}$ & $\Rightarrow$ & Clearly different \\
\hline Content & $\begin{array}{l}\text { Different based on the policy, objective, target and } \\
\text { concept of establishing the museum }\end{array}$ & $\begin{array}{l}\text { Local lifestyles and wisdoms of the community where } \\
\text { the museum was located at }\end{array}$ & $\Rightarrow$ & Unclear \\
\hline Presentation & $\begin{array}{l}\text { Bringing images, models, tools, artifacts, arts, etc. } \\
\text { to make the story and display in the glass cabinet, } \\
\text { the showroom or the place prepared }\end{array}$ & $\begin{array}{l}\text { Local lifestyles and wisdoms of the community where } \\
\text { the museum was located at and artifacts were not } \\
\text { exhibited together at any particular rooms or buildings }\end{array}$ & $\Rightarrow$ & Clearly different \\
\hline $\begin{array}{l}\text { Information } \\
\text { providing }\end{array}$ & $\begin{array}{l}\text { Curators who were responsible for guiding or } \\
\text { giving the information were available }\end{array}$ & $\begin{array}{l}\text { No curators the community would be responsible for } \\
\text { guiding or giving the information instead }\end{array}$ & $\Rightarrow$ & Clearly different \\
\hline Service & $\begin{array}{l}\text { Opened from } 9.00 \text { am- } 4.00 \mathrm{pm} \text { Closed on Monday, } \\
\text { Tuesday and official holiday the entry fee was } 20 \\
\text { baht for Thai people and } 100 \text { baht for foreigners } \\
\text { (announced in the government gazette) }\end{array}$ & Opened every day without any service charges & $\Rightarrow$ & Unclear \\
\hline $\begin{array}{l}\text { Organization } \\
\text { structure }\end{array}$ & Administered by the government & Administered by the community & $\Rightarrow$ & Unclear \\
\hline Role & $\begin{array}{l}\text { Gathering artifacts, checking, categorizing and } \\
\text { researching, recording evidence, repairing artifacts, } \\
\text { protect artifacts, exhibiting and servicing societies }\end{array}$ & $\begin{array}{l}\text { Exhibiting a story of local lifestyles and wisdoms } \\
\text { of the community where the museum was located }\end{array}$ & $\Rightarrow$ & Similar \\
\hline
\end{tabular}

community where the museums were located those artifacts were not exhibited together at any particular rooms or buildings with the key concept that artifacts would be more valued when being with their owner and told the story by their owner themselves, the living museums exhibited real lifestyles and usual lifestyles of people in the community with the key concept that needed tourists to visit the museums and experience real lifestyles and usual lifestyles of people in the community without creating any imaginations like general museums and the living museums had no curators who were responsible for guiding or giving the information people from the community would be responsible for these instead with the key concept that the community was the real owner of lifestyles, traditions and cultures; Hence, they more understood and could tell the story in the way that could not be academically explained this was told from their real different experience and based family that was why it was more attractive, interesting and emotional.

There were two living museums in Thailand with the elements that clearly indicated their significant identities as follows: the living museums did not construct buildings for exhibition, the living museums were full of artifacts pertaining to local life styles and wisdoms of the community where the museums were located those artifacts were not exhibited together at any particular rooms or buildings, the living museums exhibited real life styles and usual life styles of people in the community and the living museums had no curators who were responsible for guiding or giving the information people from the community would be responsible for these instead. It was apparent that the museum identity or creation of museum identity was really necessary for all types of museum now a days especially a living museum where was quite new in Thailand showing uniqueness, remarkableness and difference comparing to general museums, so as to interest and attract more tourists to visit a museum conforming to the concept of The Spertus Institute for Jewish Studies which was the study of globalization, museum and identity evolution, revealing that the museum development proper to the age of globalization would consider the following 7 steps: pride and right, museum for social changes, architecture, competition for capital acquisition and audience, definition of responsibility, artifact collection and storage and identity conforming to the concept of Pachari Walaipan which was the study of museum identity from Khon Kaen Provincial National Museum, revealing that the museum identity was important that the museum should have been administered for the successful operation of the museum by translating, earning the recognition of museum identity or publicizing and advertising, so that, common people would know those identities, maintaining the museum identity, managing the business of museum, conducting the related research of museum identity and working in the network with other organizations related. There were two living museums in 
Thailand: Baan Khi Lek Yai Living Museum in Chaiyaphum Province and Mae Hong Son Living Museum in Mae Hong Son Province indicating the identity through the elements of living museum which indicated the unique natures different from general museums and could be divided into 2 points as follows: to present the story of life styles and culture of the community where the museums were located, through the museum identities: museum buildings, museum artifacts, exhibition and information providing, considered the pattern different from the original one of general museums this made the living museum more tourists interested to visit museums and to present the story of lifestyle and culture of the community where the museums were located, as the content in exhibition indicating how long is the community, lifestyles, cultures, tradition, etc., that had been followed, so far, until it became the community identity and made people in the community proud that made the living museum more interesting. Baan Khi Lek Yai Living Museum in Chaiyaphum Province tried to show the identity of being Baan Khi Lek Yai Living Museum in Chaiyaphum Province whereas Mae Hong Son Living Museum tried to show the identity of being Tai people (Tai Yai) to tell that "Who they are" or "How different they are from other people" through the pattern of exhibition of the living museum used as the tool to show the identity and maintain lifestyles, traditions, rites or practices. The community participated in administering the museum, so that, the community would be aware of and proud of the community including doing the best duty of theirs. The abovementioned identity reminded "Who they are" or "How different they are from other people" from an association between themselves and other people by consideration from themselves and other people at that moment. Those people or things may have included many identities created and followed by the social process. The fact that humans considered themselves may have been different from the fact that other people considered conforming to the concept of Sayun Praichanjit revealing that the administration of local community museum was a process of managing cultural resources that created the community development and of showing the identity to people from other local communities at various levels to indicate "Who they are", "How social and cultural prosperity creates the strength of local communities" and "How they will be able to live with other people happily and stably" as they were humans as the same. Therefore, to show the identity of local communities through museum administration was considered the tool and method in the process of community process conforming to the concept of Sirirat Sisombut which was the study of community learning center and ethnic identity recovery of Song people, revealing that the museum was a new place for local people that more created their identity through a local museum responded by villagers and local academicians who needed to show the identity.

\section{CONCLUSION}

It was the study that saw the identity through the learning center or museum could be used to analyze the identity and recover the identity through the learning center where exhibited the story of ethnic identities of Song people, recovery and conservation of Song language that is to say, the museum identity and its recovery were the process of conserving and recovering Song people's cultures.

\section{SUGGESTIONS}

There should be a Participatory Action Research (PAR) on living museums by determining the area to research and studying the possibility of establishing living museums in the area by surveying if living museums to be established in the community will fulfil the needs of the community if they are different from general museums or existing cultural organizations and how to make living museums to be established the most beneficial for the community. Results should be analyzed and assessed to provide primary data for the establishment of living museums in the community. The methodology should be Participatory Action Research (PAR).

\section{REFERENCES}

Kanokmongkol, N., 2011. Living museum: Japanese peoples living museum. Ancient City J., 37: 124-133.

ONM., 2012. Manual of museum establishment and administration. Office of National Museum, Seven Printing Group, Bangkok, Thailand.

Phosrithong, P., 2011. Problematic mechanism of Thai museum. Ancient City J., 37: 72-73.

Royal Institute of Thailand, 2003. Royal Institute Dictionary B.E. 2542 1999. 1st Edn., Nan Mee Book Publications Limited Bangkok, Thailand, Pages: 600.

Srisak, V., 2002. [Thai Museums for a New Century]. The Princess Maha Chakri Sirindhorn Anthropology Center, Bankok, Thailand, (In Thai).

Walaiporn, P., 2010. Study of museum identity of khon kaen provincial national museum. Master Thesis, Silpakorn University, Phra Nakhon, Bangkok, Thailand. 